Acta Theriologica 45, Suppl. 1: 47-58, 2000.

PL ISSN 0001-7051

\title{
Karyotypic variation of the common shrew Sorex araneus in Belarus, Estonia, Latvia, Lithuania and Ukraine
}

\author{
Alina V. MISHTA, Jeremy B. SEARLE and Jan M. WÓJCIK
}

\begin{abstract}
Mishta A. V., Searle J. B. and Wójcik J. M. 2000. Karyotypic variation of the common shrew Sorex araneus in Belarus, Estonia, Latvia, Lithuania and Ukraine. [In: Evolution in the Sorex araneus group: Cytogenetic and molecular aspects. J. B. Searle and J. M. Wójcik, eds]. Acta Theriologica 45, Suppl. 1: 47-58.

Karyotypes of 55 common shrews Sorex araneus Linnaeus, 1758 from 24 geographically distinct sites in Eastern Europe (Belarus, Estonia, Latvia, Lithuania, Ukraine) were obtained using G-banding. Ten chromosome races were found, six of which had been described previously in the following countries: the Gołdap race in Poland (Fedyk 1986), the Białowieża race in Poland (Fredga and Nawrin 1977), the Pskov race in Russia (Zaitsev and Bulatova 1999), the Kiev race in Ukraine (Mishta 1994), the Lepel race in Belarus (Bulatova et al. 2000) and the Neroosa race in Russia (Bulatova et al. 2000). The four new races were characterised by the following metacentrics: $g r, h k, i p, m n, o q$ (Tallinn race), $h k, m n$ (Zuvintas race), $h k$ (Turov race) and $h i$ (Bobruysk race). The relationships of the different chromosome races of common shrew in Eastern Europe are examined.

Institute of Zoology, Ukrainian Academy of Sciences, 01601 Kiev-30, B. Khmelnitsky str. 15, Ukraine, e-mail: alina@mishta.pp.kiev.ua (AVM); Department of Biology, University of York, P.O. Box 373, York Y010 5YW, U.K., e-mail: jbs3@york.ac.uk (JBS); Mammal Research Institute, Polish Academy of Sciences, 17-230 Białowieża, Poland, e-mail: jwojcik@bison.zbs.bialowieza.pl (JMW)
\end{abstract}

Key words: Sorex araneus, chromosome races, karyotypic evolution

\section{Introduction}

The common shrew Sorex araneus Linnaeus, 1758 shows phenomenal karyotypic variability involving Robertsonian fusions and whole-arm reciprocal translocations. The diploid number of the species varies from $2 n=20$ to $2 n=33$ and numerous chromosome races have been described over its extensive distribution, each characterised by a particular set of acrocentrics and metacentrics (Searle and Wójcik 1998). Until 1995, almost all the known chromosome races were from western and central Europe, even though a larger part of the range of the common shrew occurs in eastern Europe and Siberia (ie the Former Soviet Union). Since that time, there has been an extensive investigation of the karyotypic variation in the Former Soviet Union, in a project funded by INTAS. Here we present data collected in the territory of Belarus, Estonia, Latvia, Lithuania and Ukraine to complement other studies in European Russia (Orlov et al. 1996, Zaitsev and Bulatova 1999, Bulatova et al. 2000, Kozlovsky et al. 2000) and Siberia (Polyakov et al. 1996, 1997a, b, 2000a, b). 


\section{Material and methods}

Animals were collected between summer 1996 and autumn 1998 at 14 sites of Ukraine, 4 sites of Belarus, 2 sites of Estonia, 2 sites of Latvia and 2 sites of Lithuania (Fig. 1). Shrews were caught using trapping fences and live traps.

Mitotic preparations of chromosomes were made from bone marrow and from spleen according to the method of Ford and Hamerton (1956), directly in the field. G-banding was applied in the laboratory by a modified version of Seabright's (1971) technique. The nomenclature for the karyotypes of individual shrews and of chromosome races follows Searle et al. (1991) and Hausser et al. (1994).

\section{Results and discussion}

\section{Chromosome races}

The details of karyotypes and collection sites of each shrew caught are presented in Table 1. The collection sites are mapped in Fig. 1.

As found elsewhere in the common shrew, the variable chromosomes were $g-r$. All individuals were characterised by the $\mathrm{XX} / \mathrm{XY}_{1} \mathrm{Y}_{2}$ sex chromosome system and the autosomal metacentrics $a f, b c$ and $t u$. The metacentric $j l$ was also usually present in a homozygous metacentric state, although one individual was a heterozygote carrying metacentric $j l$ and acrocentrics $j$ and $l$ (Table 1).

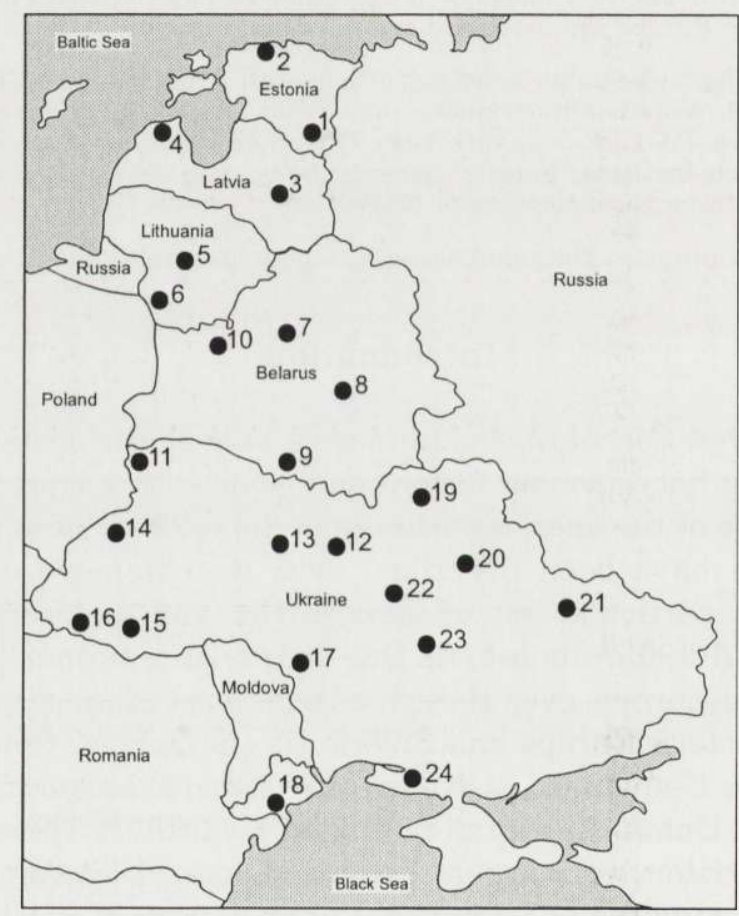

Fig. 1. Map showing collection sites (black circles) of the common shrew in Belarus, Estonia, Latvia, Lithuania and Ukraine (see Table 1). 
Often the individuals caught in different sites had different karyotypes. Although the sample sizes were small, we have tentatively named those with distinctly different karyotypes as different races, trying to apply the rules of Hausser et al. (1994) for the description of new forms. We appreciate that further study will help to define these races further.

We consider there to be ten races within the five countries that we sampled. One of these races was found in Lithuania, two each in Estonia and Latvia, three in Ukraine and four in Belarus (some races were found in more than one country). Four of the ten races have not been described previously and we first present these. Our current understanding of the distribution of all the races that we found is summarised in Fig. 2.

\section{Tallinn race}

$\mathrm{XX} / \mathrm{XY}_{1} \mathrm{Y}_{2}, a f, b c, g / r, h k, i p, j l, m n, o q, t u$

Type locality: Tallinn, NW Estonia, $59^{\circ} 25^{\prime} \mathrm{N}, 24^{\circ} 40^{\prime} \mathrm{E}$

Shrews collected from northern Estonia (Tallinn: 2 individuals) and eastern Latvia (Laudona: 2 individuals) carried the metacentrics $g r, h k$, ip, $m n, o q$ (Fig. 3). All four shrews were homozygous metacentric for all these elements, except one individual from Latvia which was heterozygous for $\mathrm{g} r$. This race is characterised by metacentric ip which is found in races in Finland, metacentrics $g r$ and $m n$ found in races in Poland and $h k$ found in both Poland and Finland. Clearly, its karyotypic characteristics reflect its geographic position along the seaboard between Poland and Finland.

\section{Zuvintas race \\ $\mathrm{XX} / \mathrm{XY}_{1} \mathrm{Y}_{2}, a f, b c, g, h k, i, j l, m / n, o, p, q, r, t u$}

Type locality: Lake Zuvintas, Alitus district, S Lithuania, $54^{\circ} 26^{\prime} \mathrm{N}, 23^{\circ} 40^{\prime} \mathrm{E}$

Six out of 7 individuals collected from two sites in Lithuania were homozygous metacentric for $h k$, and homozygous acrocentric for $g, i, m, n, o, p, q, r$. One animal was heterozygous for metacentric $m n$ (Fig. 4). As indicated above, both $h k$ and $m n$ are metacentrics found in nearby Poland.

\section{Turov race}

$\mathrm{XX} / \mathrm{XY}_{1} \mathrm{Y}_{2}, a f, b c, g, h / k, i, j l, m, n, o, p, q, r, t u$

Type locality: Turov district, S Belarus, $52^{\circ} 00^{\prime} \mathrm{N}, 27^{\circ} 56^{\prime} \mathrm{E}$

\section{Bobruysk race}

$\mathrm{XX} / \mathrm{XY}_{1} \mathrm{Y}_{2}, a f, b c, g, h / i, j l, k, m, n, o, p, q, r, t u$

Type locality: Bobruysk district, Berezina river, E Belarus, $53^{\circ} 02^{\prime} \mathrm{N}, 29^{\circ} 15^{\prime} \mathrm{E}$

Representative karyotypes for these races are shown in Figs 5 and 6. It must be noted that the Turov and Bobruysk races are represented by only one and two 
Table 1. The karyotypes of Sorex araneus from Belarus, Estonia, Latvia, Lithuania and Ukraine (only variable chromosome arms $g-r$ are indicated). Localities analysed in the present study are mapped in Fig. 1 with the codes listed here. $n$ - sample size, 2na - diploid autosome number, abbreviations of races as in Table $2{ }^{1}{ }^{1}$ - data from Orlov et al. (1996), ${ }^{2}$ - data from Bulatova et al. (2000), ${ }^{3}$ - data from Ivanitskaya (1985); no information provided on sex of individuals karyotyped, ${ }^{4}$ - data from Baker et al. (1996); no information provided on sex of individuals karyotyped, ${ }^{5}$ - data from Mishta (1994), ${ }^{6}$ preparation originated from I. Zagorodniuk, ? - unscorable preparations. M - male, F - female.

\begin{tabular}{|c|c|c|c|c|c|c|}
\hline & Locality & Latitude/Longitude & $n, \operatorname{sex}$ & 2na & Chromosome formula & Race \\
\hline & 1 & 2 & 3 & 4 & 5 & 6 \\
\hline & \multicolumn{6}{|c|}{ Estonia } \\
\hline 1 & Ruusmae & $57^{\circ} 38^{\prime} \mathrm{N}, 27^{\circ} 07^{\prime} \mathrm{E}$ & $2 \mathrm{~F}$ & 18 & $g m, h k, i p, j l, n r, o q$ & Ps \\
\hline 2 & Tallinn & $59^{\circ} 25^{\prime} \mathrm{N}, 24^{\circ} 40^{\prime} \mathrm{E}$ & $2 \mathrm{M}$ & 18 & $g r, h k, i p, j l, m n, o q$ & $\mathrm{Ta}$ \\
\hline \multicolumn{7}{|c|}{ Latvia } \\
\hline 3 & Laudona & $56^{\circ} 42^{\prime} \mathrm{N}, 26^{\circ} 11^{\prime} \mathrm{E}$ & $1 \mathrm{~F}$ & 19 & $g / r, h k, i p, j l, m n, o q$ & $\mathrm{Ta}$ \\
\hline \multirow{8}{*}{4} & & & $1 \mathrm{~F}$ & 18 & $g r, h k, i p, j l, m n, o q$ & \\
\hline & Slitere & $57^{\circ} 39^{\prime} \mathrm{N}, 22^{\circ} 19^{\prime} \mathrm{E}$ & $3 \mathrm{~F}$ & 25 & $g / r, h k, i, j l, m, n, o, p, q$ & Go \\
\hline & & & $1 \mathrm{M}$ & 24 & $g r, h k, i, j l, m, n, o, p, q$ & \\
\hline & & & $1 \mathrm{~F}$ & 24 & $g / r, h k, i, j l, m / n, o, p, q$ & \\
\hline & & & $1 \mathrm{M}$ & 23 & $g r, h k, i, j l, m / n, o, p, q$ & \\
\hline & \multicolumn{6}{|c|}{ Kaliningrad region } \\
\hline & Kurish Spit ${ }^{1}$ & $55^{\circ} 40^{\prime} \mathrm{N}, 21^{\circ} 00^{\prime} \mathrm{E}$ & $1 \mathrm{M}, 2 \mathrm{~F}$ & 22 & $g r, h k, i, j l, m n, o, p, q$ & Go \\
\hline & & & $2 \mathrm{M}, 1 \mathrm{~F}$ & 24 & $g / r, h k, i, j l, m / n, o, p, q$ & \\
\hline & & & Lithuan & & & \\
\hline 5 & Krekenava & $55^{\circ} 33^{\prime} \mathrm{N}, 24^{\circ} 00^{\prime} \mathrm{E}$ & $1 \mathrm{M}, 1 \mathrm{~F}$ & 26 & $g, h k, i, j l, m, n, o, p, q, r$ & $\mathrm{Zu}$ \\
\hline \multirow[t]{6}{*}{6} & Zuvintas & $54^{\circ} 26^{\prime} \mathrm{N}, 23^{\circ} 40^{\prime} \mathrm{E}$ & $4 \mathrm{M}$ & 26 & $g, h k, i, j l, m, n, o, p, q, r$ & $\mathrm{Zu}$ \\
\hline & & & $1 \mathrm{~F}$ & 25 & $g, h k, i, j l, m / n, o, p, q, r$ & \\
\hline & \multicolumn{6}{|c|}{ Belarus } \\
\hline & Lepel $^{2}$ & $54^{\circ} 40^{\prime} \mathrm{N}, 28^{\circ} 30^{\prime} \mathrm{E}$ & $1 \mathrm{M}$ & 19 & $g m, h k, i p, j l, n q, o / r$ & $\mathrm{Lp}$ \\
\hline & & & $1 \mathrm{~F}$ & 20 & $?$ & \\
\hline & & & $1 \mathrm{~F}$ & 21 & $?$ & \\
\hline \multirow[t]{2}{*}{7} & Besiady & $54^{\circ} 13^{\prime} \mathrm{N}, 27^{\circ} 46^{\prime} \mathrm{E}$ & $1 \mathrm{~F}$ & 22 & $g / m, h k, i / p, j l, n / q, o / r$ & Lp \\
\hline & & & $1 \mathrm{M}$ & 23 & $g / m, h k, i / p, j l, n / q, o, r$ & \\
\hline \multirow[t]{3}{*}{8} & Bobruysk & $53^{\circ} 02^{\prime} \mathrm{N}, 29^{\circ} 15^{\prime} \mathrm{E}$ & $1 \mathrm{M}, 1 \mathrm{~F}$ & 27 & $g, h / i, j l, k, m, n, o, p, q, r$ & Bo \\
\hline & Gomel $^{3}$ & $52^{\circ} 24^{\prime} \mathrm{N}, 31^{\circ} 00^{\prime} \mathrm{E}$ & 1 & 19 & $?$ & \\
\hline & & & 1 & 25 & $?$ & \\
\hline 9 & Turov & $52^{\circ} 00^{\prime} \mathrm{N}, 27^{\circ} 56^{\prime} \mathrm{E}$ & $1 \mathrm{~F}$ & 27 & $g, h / k, i, j l, m, n, o, p, q, r$ & $\mathrm{Tu}$ \\
\hline \multirow[t]{5}{*}{10} & Lesnoe Ozero & $54^{\circ} 00^{\prime} \mathrm{N}, 25^{\circ} 28^{\prime} \mathrm{E}$ & $1 \mathrm{M}, 1 \mathrm{~F}$ & 22 & $g r, h n, i k, j l, m, o, p, q$ & $\mathrm{Bi}$ \\
\hline & & & $1 \mathrm{M}$ & 23 & $g / r, h n, i k, j l, m, o, p, q$ & \\
\hline & & & $1 \mathrm{M}$ & 23 & $g, h n, i k, j l, m / p, o, q, r$ & \\
\hline & & & $1 \mathrm{M}$ & 24 & $g / r, h n, i k, j / l, m, o, p, q$ & \\
\hline & & & Ukrain & & & \\
\hline \multirow[t]{4}{*}{11} & Shatskie Ozera & $51^{\circ} 29^{\prime} \mathrm{N}, 23^{\circ} 47^{\prime} \mathrm{E}$ & $1 \mathrm{M}$ & 21 & $g r, h n, i k, j l, m / p, o, q$ & $\mathrm{Bi}$ \\
\hline & Chernobyl $^{4}$ & $51^{\circ} 12^{\prime} \mathrm{N}, 30^{\circ} 17^{\prime} \mathrm{E}$ & 14 & $24-26$ & ? & \\
\hline & $\mathrm{Kiev}^{5}$ & $50^{\circ} 23^{\prime} \mathrm{N}, 30^{\circ} 26^{\prime} \mathrm{E}$ & $1 \mathrm{~F}$ & 23 & $g / m, h i, j l, k o, n, p, q, r$ & $\mathrm{Ki}$ \\
\hline & & $50^{\circ} 23^{\prime} \mathrm{N}, 30^{\circ} 28^{\prime} \mathrm{E}$ & $1 \mathrm{~F}$ & 22 & $g m, h i, j l, k o, n, p, q, r$ & \\
\hline
\end{tabular}


Table 1 - concluded.

\begin{tabular}{|c|c|c|c|c|c|c|}
\hline & 1 & 2 & 3 & 4 & 5 & 6 \\
\hline 12 & Boyarka & $50^{\circ} 19^{\prime} \mathrm{N}, 30^{\circ} 18^{\prime} \mathrm{E}$ & $1 \mathrm{M}$ & 23 & $g / m, h i, j l, k o, n, p, q, r$ & $\mathrm{Ki}$ \\
\hline \multirow[t]{3}{*}{13} & Zhitomir & $50^{\circ} 17^{\prime} \mathrm{N}, 28^{\circ} 33^{\prime} \mathrm{E}$ & $1 \mathrm{M}$ & 24 & $g, h i, j l, k o, m, n, p, q, r$ & $\mathrm{Ki}$ \\
\hline & & & $1 \mathrm{M}, 1 \mathrm{~F}$ & 24 & $g / m, h i, j l, k / o, n, p, q, r$ & \\
\hline & & & $1 \mathrm{M}$ & 25 & $g / m, h i, j l, k, o, n, p, q, r$ & \\
\hline 14 & Roztochie & $49^{\circ} 57^{\prime} \mathrm{N}, 23^{\circ} 45^{\prime} \mathrm{E}$ & $1 \mathrm{M}$ & 24 & $g / m, h i, j l, k / o, n, p, q, r$ & $\mathrm{Ki}$ \\
\hline 15 & Mykulychyn & $48^{\circ} 23^{\prime} \mathrm{N}, 24^{\circ} 36^{\prime} \mathrm{E}$ & $2 \mathrm{M}$ & 23 & $g m, h i, j l, k / o, n, p, q, r$ & $\mathrm{Ki}$ \\
\hline \multirow[t]{2}{*}{16} & Rahov & $48^{\circ} 02^{\prime} \mathrm{N}, 24^{\circ} 10^{\prime} \mathrm{E}$ & $1 \mathrm{M}$ & 25 & $g, h i, j l, k / o, m, n, p, q, r$ & $\mathrm{Ki}$ \\
\hline & & & $1 \mathrm{~F}$ & 24 & $g / m, h i, j l, k / o, n, p, q, r$ & \\
\hline \multirow[t]{2}{*}{17} & Britavka & $48^{\circ} 10^{\prime} \mathrm{N}, 29^{\circ} 08^{\prime} \mathrm{E}$ & $1 \mathrm{M}$ & 22 & $g m, h i, j l, k o, n, p, q, r$ & $\mathrm{Ki}$ \\
\hline & & & $1 \mathrm{~F}$ & 23 & $g / m, h i, j l, k o, n, p, q, r$ & \\
\hline 18 & Vilkovo & $45^{\circ} 25^{\prime} \mathrm{N}, 29^{\circ} 35^{\prime} \mathrm{E}$ & $1 \mathrm{M}, 1 \mathrm{~F}$ & 24 & $g / m, h i, j l, k / o, n, p, q, r$ & $\mathrm{Ki}$ \\
\hline 19 & Berezivka & $51^{\circ} 22^{\prime} \mathrm{N}, 32^{\circ} 09^{\prime} \mathrm{E}$ & $1 \mathrm{~F}$ & 18 & go, hi, jl, kr, mn,pq & $\mathrm{Ne}$ \\
\hline 20 & Tishki & $50^{\circ} 07^{\prime} \mathrm{N}, 33^{\circ} 06^{\prime} \mathrm{E}$ & $1 \mathrm{M}$ & 18 & go, hi, jl, kr, mn, pq & $\mathrm{Ne}$ \\
\hline 21 & Zmiev & $49^{\circ} 37^{\prime} \mathrm{N}, 36^{\circ} 19^{\prime} \mathrm{E}$ & $1 \mathrm{M}, 1 \mathrm{~F}$ & 18 & go, $h i, j l, k r, m n, p q$ & $\mathrm{Ne}$ \\
\hline \multirow[t]{6}{*}{22} & Kanev & $49^{\circ} 43^{\prime} \mathrm{N}, 31^{\circ} 30^{\prime} \mathrm{E}$ & $1 \mathrm{~F}$ & 21 & $g, h i, j l, k / r, m n, o, p q$ & $\mathrm{Ne}$ \\
\hline & & & $1 \mathrm{~F}$ & 23 & $g, h i, j l, k / r, m n, o, p, q$ & \\
\hline & Kanev & $49^{\circ} 43^{\prime} \mathrm{N}, 31^{\circ} 30^{\prime} \mathrm{E}$ & $5 \mathrm{M}, 1 \mathrm{~F}$ & 20 & $?$ & \\
\hline & & & $1 \mathrm{M}, 3 \mathrm{~F}$ & 21 & $?$ & \\
\hline & & & $2 \mathrm{M}$ & 22 & $?$ & \\
\hline & Brovary ${ }^{6}$ & $50^{\circ} 30^{\prime} \mathrm{N}, 30^{\circ} 45^{\prime} \mathrm{E}$ & $1 \mathrm{M}$ & 19 & $?$ & \\
\hline \multirow[t]{2}{*}{23} & Vodianoye & $48^{\circ} 45^{\prime} \mathrm{N}, 32^{\circ} 32^{\prime} \mathrm{E}$ & $2 \mathrm{~F}$ & 20 & $g / o, h i, j l, k / r, m n, p q$ & $\mathrm{Ne}$ \\
\hline & & & $1 \mathrm{M}$ & 21 & $g, h i, j l, k / r, m n, o, p q$ & \\
\hline 24 & Golaja Pristan' & $46^{\circ} 32^{\prime} \mathrm{N}, 32^{\circ} 30^{\prime} \mathrm{E}$ & $2 \mathrm{M}$ & 18 & go, $h i, j l, k r, m n, p q$ & $\mathrm{Ne}$ \\
\hline
\end{tabular}

Table 2. Characteristics of the chromosome races found in Belarus, Estonia, Latvia, Lithuania and Ukraine, including a reference to the first description in each case.

\begin{tabular}{llll}
\hline Race & \multicolumn{1}{c}{ Distribution } & \multicolumn{1}{c}{ Karyotype } & \multicolumn{1}{c}{ References } \\
\hline Tallinn (Ta) & N Estonia, E Latvia & $g / r, h k, i p, j l, m n, o q$ & This study \\
Gołdap (Go) & NE Poland, Kaliningrad, & $g / r, h / k, i, j l, m / n, o, p, q$ & Fedyk 1986 \\
& W Latvia & & \\
Zuvintas (Zu) & Lithuania & $g, h k, i, j l, m / n, o, p, q, r$ & This study \\
Turov (Tu) & S Belarus & $g, h / k, i, j l, m, n, o, p, q, r$ & This study \\
Lepel (Lp) & N Belarus & $g / m, h k, i / p, j l, n / q, o / r$ & Bulatova et al. 2000 \\
Pskov (Ps) & SE Estonia, & $g m, h k, i p, j l, n r, o q$ & Zaitsev and Bulatova 1999 \\
& NW European Russia & & \\
Białowieża (Bi) & E Poland, W Belarus, & $g / r, h / n, i k, j l l, m / p, o, q$ & Fredga and Nawrin 1977 \\
& NW Ukraine & & \\
Bobruysk (Bo) & E Belarus & $g, h / i, j l, k, m, n, o, p, q, r$ & This study \\
Kiev (Ki) & W Ukraine & $g / m, h i, j l, k / o, n, p, q, r$ & Mishta 1994 \\
Neroosa (Ne) & W European Russia, & $g / o, h i, j / l, k / r, m n, p / q$ & Bulatova et al. 2000 \\
& E Ukraine & & \\
\hline
\end{tabular}




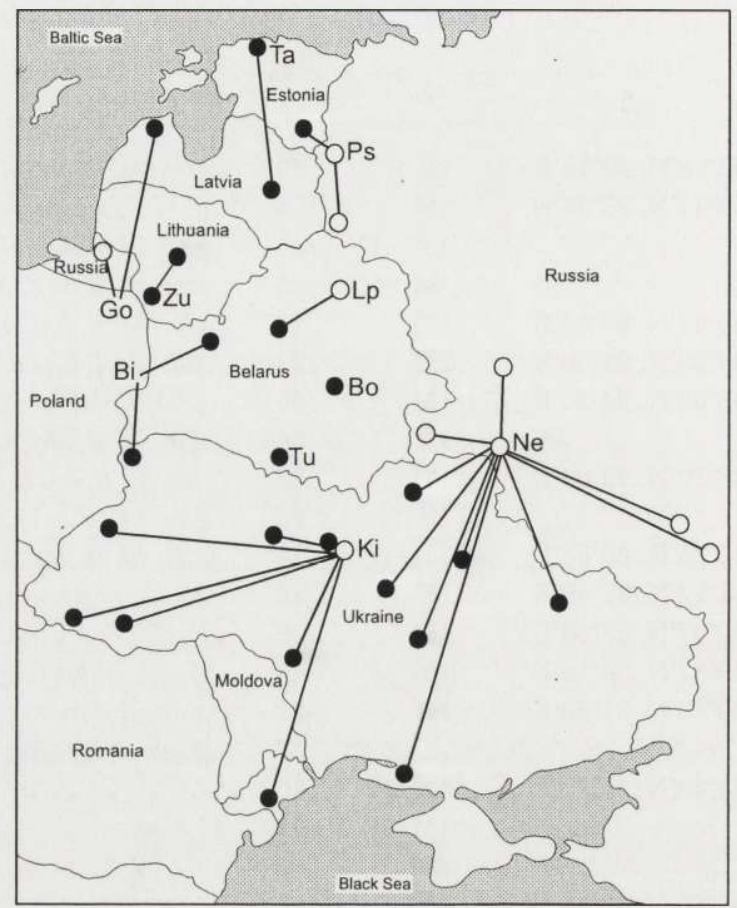

Fig. 2. The distribution of chromosome races in Belarus, Estonia, Latvia, Lithuania, Ukraine and the Kaliningrad region (see Table 2), based on data from the present study (black circles) and samples (open circles) from Mishta (1994), Orlov et al. (1996), Zaitsev and Bulatova (1999) and Bulatova et al. (2000). Abbreviations (as in Table 2) indicate localities of the first description of each race and circles connected by continuous lines show sites with the same karyotypes. See Wójcik (1993) and Fedyk (1995) for details on the distribution of the Gołdap and Białowieża races in Poland.

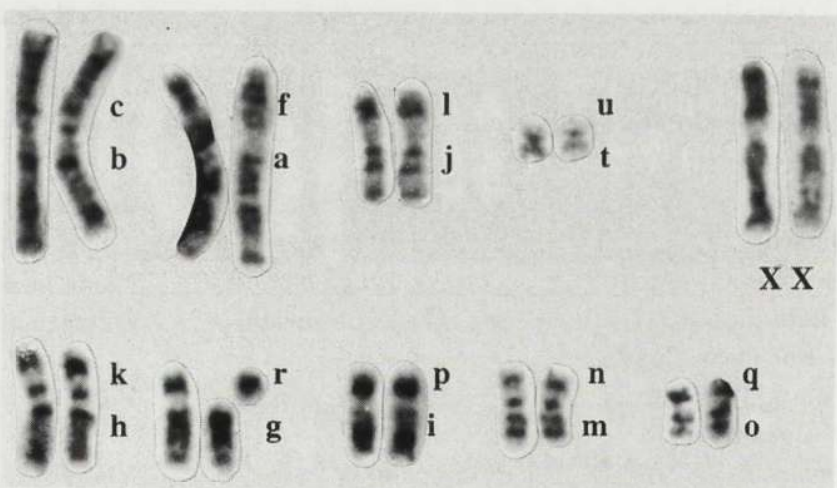

Fig. 3. G-banded karyotype of Sorex araneus of the Tallinn race. 

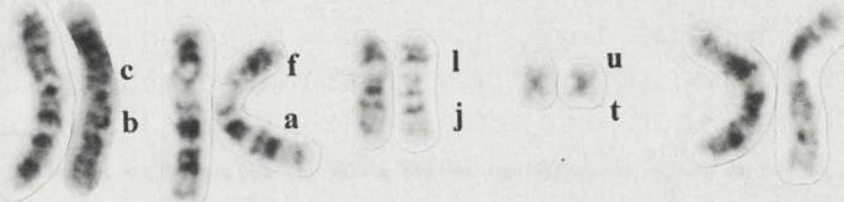

X X

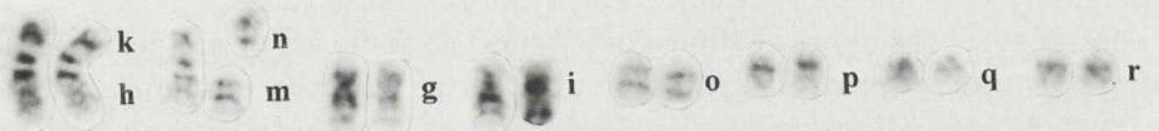

Fig. 4. G-banded karyotype of Sorex araneus of the Zuvintas race.

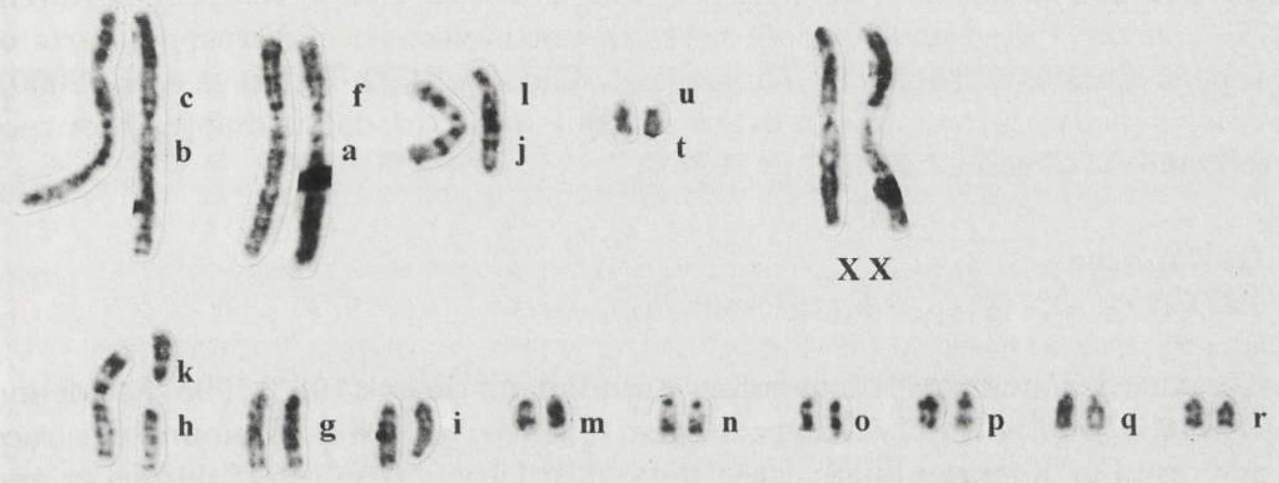

Fig. 5. G-banded karyotype of Sorex araneus of the Turov race.

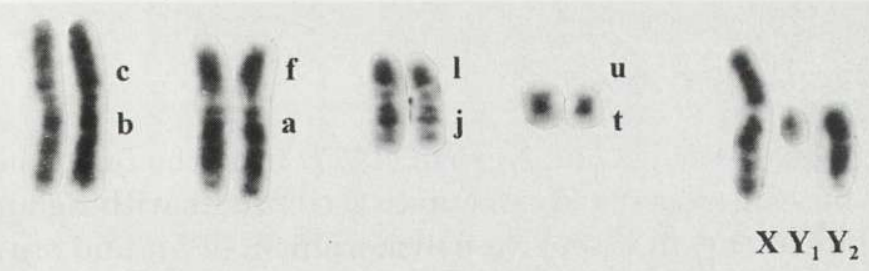

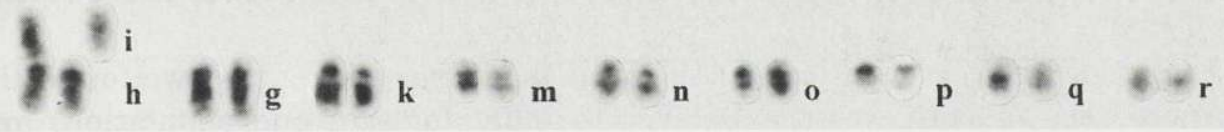

Fig. 6. G-banded karyotype of Sorex araneus of the Bobruysk race. 
specimens, respectively, and so must be considered highly tentative. However, these individuals have more acrocentric karyotypes $(2 \mathrm{na}=27)$ than any other shrews so far collected from Belarus. All the other shrews that we collected and those of Bulatova et al. (2000) had an autosome number of 19-24 there. Ivanitskaya (1985) found a specimen in the vicinity of Gomel with $2 \mathrm{na}=25$.

The Turov race is clearly very similar to the Zuvintas race of Lithuania, but the populations that define these races are well separate (about $500 \mathrm{~km}$ apart: Fig. 2) and no polymorphism for $h k$ was detected in the Zuvintas race.

The Bobruysk race is of interest because it has the same set of metacentrics and acrocentrics as races from elsewhere in the range of the common shrew: in north-eastern Poland (Banaszek et al. 1996) and to the south and east of Lake Baikal (Král et al. 1981). But these other races are characterised by polymorphism for $j l$ rather than $h i$.

The remaining six chromosome races that we found in Ukraine, Belarus and the Baltic States have been described previously, four in neighbouring countries (Fig. 2): the Gołdap and Białowieża races in Poland (Fedyk 1986, Fredga and Nawrin 1977) and the Pskov and Neroosa races in north-western and western parts of European Russia, respectively (Zaitsev and Bulatova 1999, Bulatova et al. 2000). The Lepel race was first found in Belarus by Bulatova et al. (2000) and the Kiev race first found in Ukraine by Mishta (1994).

Gołdap race

$\mathrm{XX} / \mathrm{XY}_{1} \mathrm{Y}_{2}, a f, b c, g / r, h / k, i, j l, m / n, o, p, q, t u$

This race is found locally in north-eastern Poland (Fedyk 1986, 1995, Fedyk and Leniec 1987) and in the Kaliningrad region (Orlov et al. 1996). We found this race in one population on the Baltic coast of western Latvia. Arm combinations gr and $m n$ were polymorphic in the Latvian samples; these polymorphisms plus that involving $h k$ have been found elsewhere in the range of this race. The Gołdap race is almost certainly found elsewhere in western Latvia and western Lithuania (Fig. 2).

Białowieża race

$\mathrm{XX} / \mathrm{XY}_{1} \mathrm{Y}_{2}, a f, b c, g / r, h / n, i k, j / l, m / p, o, q, t u$

This race was first described by Fredga and Nawrin (1977) from the Białowieża Primeval Forest. It is distributed in eastern Poland up to the borders with Belarus and Ukraine and is characterised by an extensive polymorphism of $h n$ and $m p$ at the northern and western boundaries of the race (Fedyk 1980, 1982, 1995, Wójcik 1991, 1993).

Given its known distribution in Poland, it is not surprising that we found the Białowieża race in both western Belarus (5 individuals in one population) and north-western Ukraine (one individual). These six individuals displayed polymorphism for autosomes $j l, g r$ and $m p$. 


\section{Pskov race}

$\mathrm{XX} / \mathrm{XY}_{1} \mathrm{Y}_{2}, a f, b c, g m, h k, i p, j l, n r, o q, t u$

This race was first described by Zaitsev and Bulatova (1999) in north-western Russia. We found shrews with the same chromosomal characteristics nearby, in one population in south-eastern Estonia (Ruusmae). Both individuals caught had a homozygous metacentric karyotype.

$$
\begin{aligned}
& \text { Lepel race } \\
& \mathrm{XX} / \mathrm{XY}_{1} \mathrm{Y}_{2}, a f, b c, g / m, h k, i / p, j l, n / q, o / r, t u
\end{aligned}
$$

Bulatova et al. (2000) found this race at one locality in northern Belarus. We found it at a second site (Besiady). One of the individuals was heterozygous for four different arm combinations, the other was a triple heterozygote.

$$
\begin{aligned}
& \text { Kiev race } \\
& \mathrm{XX} / \mathrm{XY}_{1} \mathrm{Y}_{2}, a f, b c, g / m, h i, j l, k / o, n, p, q, r, t u
\end{aligned}
$$

This race was first described from the vicinity of Kiev (Mishta 1994). We found this race in 7 further sites in western Ukraine (Boyarka, Zhitomir, Roztochie, Mykulychyn, Rahov, Britavka, Vilkovo). The polymorphisms involving arm combinations $g m$ and $k o$ were widespread.

So, we now know the range of the Kiev race with some confidence. It is distributed over much of western Ukraine from the Carpathian mountains in the extreme west to the Danube delta in the south and Kiev in the north (Fig. 2). It may be found even further north than this. The conventional preparations of Baker et al. (1996) on shrews from Chernobyl showed an autosome number of 24 to 26 compatible with the Kiev race. Shrews with a karyotype similar to the Kiev race were found in eastern Slovakia, not far from the Ukrainian border (Zima and Král 1985). The Danube delta in Romania is inhabited by shrews with the karyotype of the Ulm race (Zima 1983).

Neroosa race

$\mathrm{XX} / \mathrm{XY}_{1} \mathrm{Y}_{2}, a f, b c, g / o, h i, j / l, k / r, m n, p / q, t u$

This race was first described by Bulatova et al. (2000). We found it in six sites from eastern Ukraine and it can be presumed to be the predominant race there (Fig. 2). At four of the sites (6 shrews) all individuals had a fully metacentric karyotype, but at the two sites to the west of the river Dniper (Vodianoye and Kanev), there was polymorphism for arm combinations go, $k r$ and $p q$. The Neroosa race is found in neighbouring parts of western European Russia (Bulatova et al. 2000).

\section{Relationships with other chromosome races}

The characteristics of the ten chromosome races are summarised in Table 2. It is noticeable that most of the races possess metacentric $h k$. This metacentric is also found in the Łęgucki Młyn race (Wójcik 1986) and Gołdap race (Fedyk 1986, 1995) 
in Poland and in the Lemi race (Halkka et al. 1987) in south-eastern Finland. So, our data allow the range of $h k$ to be determined: it occurs along the coast of the Baltic Sea from north-eastern Poland to south-eastern Finland. Further sampling is needed to establish whether the site with metacentric $h k$ to the south of Belarus is isolated or whether there is a link to populations with $h k$ to the north. This may be crucial to an understanding of the origin and spread of this particular metacentric.

Also of interest are the distributions of metacentrics $g r$ and $i p$. We have shown that $g r$ occurs beyond eastern Poland, not only through the presence of the Gołdap and Białowieża races in more easterly countries, but also with the Tallinn race. Metacentric gr must now be considered a metacentric characteristic of the coastal regions of Estonia, Latvia and Lithuania as well as eastern Poland.

Likewise, our study and that of Bulatova et al. (2000) have added to the distribution of $i p$. Races with this metacentric occur far beyond the Finnish range originally described by Halkka et al. (1987). The metacentric occurs in the Tallinn race of Estonia and Latvia, the Lepel race of Belarus and the Pskov race of European Russia and Estonia. It appears that this metacentric may have originated in the Ural Mts before spreading to Finland (Polyakov et al. 2000b); there is clearly a need to understand how it penetrated into the extreme western parts of European Russia and the Baltic States as well.

One of the most interesting races that we have been able to delimit with some accuracy is the Kiev race. It is characterised by the metacentrics $g m$ and $h i$, well known to occur over much of western Europe (Searle 1984, Wójcik 1993, Searle and Wójcik 1998). These metacentrics occur in European Russia as well, within the widespread Moscow race (Aniskin and Lukianova 1989, Orlov et al. 1996, Bulatova et al. 2000). Thus, the 'karyotypic group' (Hausser et al. 1994) that has been best documented: the West European Karyotypic Group (Searle 1984), not only occurs over much of western Europe but is also well-represented in eastern Europe as well. However, while the Kiev race appears to be part of a continuous distribution of the West European Karyotypic Group extending to Great Britain in the west, the Kiev race appears to be geographically isolated from the Moscow race. The Neroosa race occurs in between these forms. The Neroosa race is characterised by metacentrics go and $h i$, and can be derived from the Moscow race by a single whole-arm reciprocal translocation (Bulatova et al. 2000). In this way, the West European Karyotypic Group and its derivatives can be considered to have a single continuous range.

Several of the races that we have found in Belarus, Estonia, Latvia, Lithuania and Ukraine have karyotypes including metacentrics characteristic of more than one lineage. Thus, the Tallinn race has metacentrics $g r$ and $h k$ characteristic of lineages associated with Poland as well as ip associated with Finland. The Lepel and Pskov races also carry $h k$ and $i p$ and additionally gm, one of the widespread metacentrics of western Europe. This apparent reticulate evolution will be considered in more depth in a later phylogenetic paper utilising the complete data set collected during the INTAS project. Likewise, the colonisation history of all the races and karyotypic groups that we describe here will be considered in that paper. 
Also of interest are the two races within Belarus with highly acrocentric karyotypes: the Bobruysk and Turov races. Previously races with acrocentric karyotypes have been found in peripheral regions of the range of the common shrew: the French Alps, Massif Central in France, Macedonia, northern Poland, the coast of Finland and Lake Baikal (Zima et al. 1994, Searle and Wójcik 1998). The Bobruysk and Turov races occur in the heart of the east European range of the common shrew. Clearly, further sampling is required to elucidate this situation.

Acknowledgements: We thank I. Brauna (Slitere Reserve, Latvia) for her help in collecting shrews, and J. Ozolins, A. Milutin, H. Valdmann, A. Kerk, R. Bashkite, V. Jakstas, the administration of Tallinn Zoo (Estonia), Zuvintas Reserve (Lithuania), Teichi Reserve (Latvia) and Pripiatsky Reserve (Belarus) for help with accommodation. We are grateful to J. Zima for comments on the manuscript. The study was supported by INTAS (93-1463).

\section{References}

Aniskin V. M. and Lukianova I. V. 1989. [A new chromosome race and analysis of hybridization zone of two karyoforms of Sorex araneus (Insectivora, Soricidae)]. Doklady Akademii Nauk SSSR 309: 1260-1262. [In Russian]

Baker R. J., Hamilton M. J., Van Den Bussche R. A., Wiggins L. E., Sugg D. W., Smith M. H., Lomakin M. D., Gaschak S. P., Bundova E. G., Rudenskaya G. A. and Chesser R. K. 1996. Small mammals from the most radioactive sites near the Chornobyl nuclear power plant. Journal of Mammalogy 77: 155-170.

Banaszek A., Ratkiewicz M., Fedyk S., Szałaj K. and Chetnicki W. 1996. The chromosomes and isoenzymes in marginal populations of the common shrew (Sorex araneus) in the Vistula Delta. Zeitschrift für Säugetierkunde 61: 65-72.

Bulatova N., Searle J. B., Bystrakova N., Nadjafova R., Shchipanov N. and Orlov V. 2000. The diversity of chromosome races in Sorex araneus from European Russia. [In: Evolution in the Sorex araneus group: Cytogenetic and molecular aspects. J. B. Searle and J. M. Wójcik, eds]. Acta Theriologica 45, Suppl. 1: 33-46.

Fedyk S. 1980. Chromosome polymorphism in a population of Sorex araneus L. at Białowieża. Folia Biologica (Kraków) 28: 83-120.

Fedyk S. 1982. Further studies on the chromosome polymorphism of the common shrew. Acta Theriologica 27: 149-153.

Fedyk S. 1986. Genetic differentiation of Polish populations of Sorex araneus L. II. Possibilities of gene flow between chromosome races. Bulletin of the Polish Academy of Sciences, Biological Sciences 34: 161-171.

Fedyk S. 1995. [Regional differentiation and hybrid zones between chromosomal races of Sorex araneus L. in north-eastern Poland]. Dissertationes Universitatis Varsoviensis 439: 1-125. [In Polish]

Fedyk S. and Leniec H. 1987. Genetic differentiation of Polish populations of Sorex araneus L. I. Variability of autosome arm combinations. Folia Biologica (Kraków) 35: 57-68.

Ford C. E. and Hamerton J. L. 1956. A colchicine, hypotonic citrate, squash sequence for mammalian chromosomes. Stain Technology 31: 247-251.

Fredga K. and Nawrin J. 1977. Karyotype variability in Sorex araneus L. (Insectivora, Mammalia). Chromosomes Today 6: 153-161.

Halkka L., Söderlund V., Skarén U. and Heikkilä J. 1987. Chromosomal polymorphism and racial evolution of Sorex araneus L. in Finland. Hereditas 106: 257-275.

Hausser J., Fedyk S., Fredga K., Searle J. B., Volobouev V., Wójcik J. M. and Zima J. 1994. Definition and nomenclature of the chromosome races of Sorex araneus. Folia Zoologica 43, Suppl. 1: 1-9.

Ivanitskaya E. Yu. 1985. [Taxonomic and cytogenetic analysis of transberingean links in shrews (Sorex, Insectivora) and pikas (Ochotona, Lagomorpha)]. Ph D Thesis, Moscow University, Moscow: 1-25. [In Russian] 
Kozlovsky A., Orlov V., Okulova N., Kovalskaya J. and Searle J. B. 2000. Chromosome studies on common shrews from northern and central parts of European Russia. [In: Evolution in the Sorex araneus group: Cytogenetic and molecular aspects. J. B. Searle and J. M. Wójcik, eds]. Acta Theriologica 45, Suppl. 1: 27-31.

Král B., Aniskin V. M. and Volobouev V. T. 1981. Karyotype variability in Siberian populations of Sorex araneus (Soricidae, Insectivora). Folia Zoologica 30: 23-37.

Mishta A. 1994. A karyological study of the common shrew, Sorex araneus (Insectivora, Soricidae) in Ukraine: First results. Folia Zoologica 43, Suppl. 1: 37-42.

Orlov V., Bulatova N., Kozlovsky A., Nadjafova R. and Searle J. B. 1996. Karyotypic variation of the common shrew (Sorex araneus) in European Russia: preliminary results. Hereditas 125: 117-121.

Polyakov A. V., Borodin P. M., Lukáčová L., Searle J. B. and Zima J. 1997a. The hypothetical Old-Northern chromosome race of Sorex araneus found in the Ural Mts. Annales Zoologici Fennici 34: 139-142.

Polyakov A. V., Chadova N. B., Rodionova M. I., Panov V. V., Dobrotvorsky A. K., Searle J. B. and Borodin P. M. 1997b. Novosibirsk revisited 24 years on: chromosome polymorphism in the Novosibirsk population of the common shrew Sorex araneus L. Heredity 79: 172-177.

Polyakov A. V., Volobouev V. T., Borodin P. M. and Searle J. B. 1996. Karyotypic races of the common shrew (Sorex araneus) with exceptionally large ranges: the Novosibirsk and Tomsk races of Siberia. Hereditas 125: 109-115.

Polyakov A. V., Zima J., Banaszek A., Searle J. B. and Borodin P. M. 2000a. New chromosome races of the common shrew Sorex araneus from Eastern Siberia. [In: Evolution in the Sorex araneus group: Cytogenetic and molecular aspects. J. B. Searle and J. M. Wójcik, eds]. Acta Theriologica 45, Suppl. 1: 11-17.

Polyakov A. V., Zima J., Searle J. B., Borodin P. M. and Ladygina T. 2000b. Chromosome races of the common shrew Sorex araneus in the Ural Mts: a link between Siberia and Scandinavia? [In: Evolution in the Sorex araneus group: Cytogenetic and molecular aspects. J. B. Searle and J. M. Wójcik, eds]. Acta Theriologica 45, Suppl. 1: 19-26.

Seabright M. A. 1971. A rapid banding technique for human chromosomes. Lancet 2: 971-972.

Searle J. B. 1984. Three new karyotypic races of the common shrew Sorex araneus (Mammalia: Insectivora) and a phylogeny. Systematic Zoology 33: 184-194.

Searle J. B., Fedyk S., Fredga K., Hausser J. and Volobouev V. T. 1991. Nomenclature for the chromosomes of the common shrew (Sorex araneus). Mémoires de la Société Vaudoise des Sciences Naturelles 19: 13-22.

Searle J. B. and Wójcik J. M. 1998. Chromosomal evolution: The case of Sorex araneus. [In: Evolution of shrews. J. M. Wójcik and M. Wolsan, eds]. Mammal Research Institute, Polish Academy of Sciences, Białowieża: 219-268.

Wójcik J. M. 1986. Karyotypic races of the common shrew (Sorex araneus L.) from northern Poland. Experientia 42: 960-962.

Wójcik J. M. 1991. Chromosomal polymorphism in the common shrew Sorex araneus and its adaptive significance. Mémoires de la Société Vaudoise des Sciences Naturelles 19: 51-62.

Wójcik J. M. 1993. Chromosome races of the common shrew Sorex araneus in Poland: a model of karyotype evolution. Acta Theriologica 38: 315-338.

Zaitsev M. V. and Bulatova N. Sh. 1999. [Shrews of two western regions of Pskov district and their chromosome diagnoses (Sorex, Soricidae, Insectivora)]. Zoologicheskii Zhurnal 78: 600-605. [In Russian]

Zima J. 1983. Chromosomes of the harvest mouse, Micromys minutus, from the Danube Delta (Muridae, Rodentia). Folia Zoologica 32: 19-22

Zima J. and Král B. 1985. Karyotype variability of Sorex araneus in central Europe (Soricidae, Insectivora). Folia Zoologica 34: 235-243.

Zima J., Macholán M., Filippucci M. G., Reiter A., Andreas M., Lípa M. and Kryštufek B. 1994. Karyotypic and biochemical status of certain marginal populations of Sorex araneus. Folia Zoologica 43, Suppl. 1: 43-51.

Received 28 December 1999, accepted 22 January 2000. 